\title{
The dissolution of the Soviet Union and complex state construction processes. Two differentiated secession models in the Republic of Moldova: Gagauzia and Transnistria
}

\section{José A. LÓPEZ JIMÉNEZ*}

\begin{abstract}
The purpose of this article is to analyse an unknown case of two different secessionist processes in the Republic of Moldova-Gagauzia and Transnistria-started in the framework of the decomposition of the Soviet Union. Both of them emerged as a virulent reaction to the irruption of a pro-Romanian Moldovan nationalism with a radical irredentist character.
\end{abstract}

Keywords: Russia-Moldova-Gagauzia-Transnistria relationships - Frozen Conflicts - Secession - Self-determination Succession of States

\section{(A) INTRODUCTION}

Post-Soviet space has created —and continues to do so- a lot of examples of unsolved complex states' succession. There are additional difficulties in order to explain a political event caused after the former Soviet Union's dissolution from an international and internal legal perspective.

Taking into account the international and the soviet internal law perspective we cannot consider a general framework without an essential political analysis that is impacting-from my point of view—relevant aspects of this case study. First of all, the Russian Federation's recognition of the legitimate successor role in the international community after the dissolution of the former Soviet Union should be noted. It was confirmed by direct succession, without the need to ask- ex novo-the recognition as a new member in United Nations, including the permanence in the privileged Security Council. But also by the development of new trends in foreign policy unfolded by the new Russian state since the independence and new configuration: we are talking about a new role and tool used by Moscow. Interventionism policy has been the most frequent reaction from the Kremlin

* Professor of Public International Law, Universidad Pontificia Comillas/ICADE, Madrid. 
versus the different secessionist processes. The relationship between Russia and the rest of the new independent republics has been substantially modified: the near abroad is being object of a progressive territorial fragmentation. Nevertheless, this worrying process is building an unstable geopolitics area in the shared neighbourhood with the European Union. So far, Western reaction according to international law has been non-recognition policy for the whole of new puppet states. The current situation on these conflicts is not moving in the way to consolidate de iure what has been building de facto in the former Soviet Union territory since the last twenty-six years.

The creation of new states has been the main consequence of the former Soviet dissolution. This historical event transformed one federal republic in fifteen new states overnight after Belavezha Treaty. Complex national construction processes started in all cases when they were facing the challenge to keep territorial integrity due to the different internal secessionist movements. The origin of these processes started during the final Soviet Union years, in the separatist context of the different federal republics, although it also shook several political administrative entities: the autonomous republics and regions. The most virulent political disintegration faced by an empire during the twentieth century was qualified by Putin as the biggest geopolitical catastrophe. The legal consequence was clear according to the former soviet internal legal orders: in the last Soviet Constitution of 1977 , the voluntary character of the association of federated republics can activate Article 70 as well as Article 72 -right to separate freely from the federation. What was the hardest thing to do in this decomposition context? First of all, the last desperate attempt was approved by Supreme Soviet on April 7 1990: Secession Law tried to regulate the conditions to proceed in the legal republic secessions. Moscow wanted to get enough time for stopping the cascade of the independence declarations. Nevertheless, this new internal legal provision provoked what it wanted to avoid: Baltic Republics' declarations of sovereignty opened Pandora's box and the rest of the republics followed the marked path to independence. All these Soviet domestic legal orders had a single territorial entity as a beneficiary: only the fifteen federated republics could exercise the right of secession. The right to self-determination was not reserved for other territorial entities with different status in the former Soviet Union: neither the autonomous republics - Chechnya, for instance- nor autonomous regions, could use internal or international legal order to get independence from the federal state. In the same way, all the new republics had to build their respective path to independence in which the different national building processes should define the new status for these territorial units. Different domestic solutions were adopted according to the new states and each Constitution.

The whole of frozen conflicts - also protracted or without a definitive solution - that we can analyse in the former soviet space are developing their own dynamics. European Union 
shared neighbourhood is marked by a diversity of territorial secessionist entities who share the same interventionist model: external Russian patronage linked to their geopolitical and geostrategic interests in the entire region.

The Moldavian case has been suffering a double secessionist process in the Gagauzia and Transnistria regions. Both of them have been managed similarly from Chisinau but with significative different results mainly due to Moscow's decision to maintain pressure on Moldova and its support to the authorities of Tiraspol through a complete package of tools. Especially the presence of the Russian armed forces since the beginning of their path as an independent state.

During the first stage of the conflicts in both regions, ideological component was the most

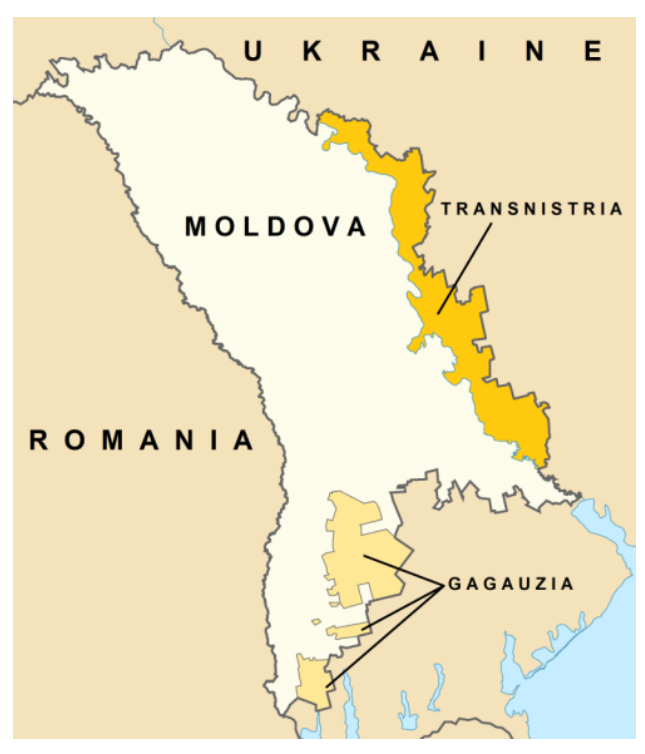

thorough analysis.

After the sovereignty declaration in the republic - during 1990- the evolution in both entities was quite different. Not only initiating their own secessionist movements but also starting statehood through the construction of independent institutions -executive, legislative, judicial, education, currency, security system - Transnistria's model represents de facto statehood consolidation existing for over 25 years. This "puppet state" has survived due to Russian intervention regardless of the continuous International Law's violations. Otherwise, the survival of Transnistria separated from Moldova would have been impossible. This support from Moscow has not been present in Gagauzia. This important nuance can explain the path to the Gagauz Yeri Autonomy within the Moldova framework. That internal

Moldova is the current official name recognized in the Constitution (1994) of the Republic of Moldova and in the United Nations. The main purpose was trying to differentiate the Soviet period and the new independent republic. 
self-determination according to the Moldova's Constitution has been a satisfactory solution avoiding secessionist alternatives.

Historical context is really relevant to understand the origin of both separatist phenomes but it is impossible to address in this article and it is very well researched in several works. Nevertheless, nationalism and identity were the main reasons used to explain -especially at the beginning - the confrontations between the different ethnic minorities or between the centre and the periphery. ${ }^{2}$

\section{(B) SECESSIONISM IN GAGAUZIA}

As the secessionist case developed in Transnistria, the southern districts of the republic led a similar movement within Gagauze minority. The main reason adopted as a protest flag was the ghost of Moldovan reunification with Romania. That is why the clashes between an irredentist Moldovan nationalism and the rest of the ethnic minorities started from the moment in which the main goal was considered to break with the Soviet Union for joining, after that, with the motherland Romania. This pendular movement tried to recover the old status within Romania. That is to say to return to the interwar period. This ethnic minority of Turkish origin professes the orthodox religion and it was concentrated in five southern districts. They are around 150.000 people $-3.5 \%$ of the total population in the republic-. They declared their independence in august 1990, one year after the adoption of the linguistic laws. That was the key point considered by the Gagauzes, but also by the Slavic minorities living in Transnistria, as the breaking off with the Soviet Union. Moldovan identity was history. Official language was the Romanian because of the identification between Moldovan and Romanian language. Chisinau was under Moldovan Popular Front control but the secessionist claims were to remain within the Soviet Union, even though the Republic of Moldova was a unitary state-according to the Constitution of 1994 -Article Iro included the possibility of establishing special statutes of autonomy. This was especially designed for Transnistria and Gagauzia. In the future, this possibility can be reached through different organic laws. In a precise way, the concept of autonomy designed for the public administration within the administrative-territorial units "shall be based on the principles of local autonomy, decentralisation of public services, eligibility of the local public administration authorities and consultation of citizens on local problems of special interests" (Article $\operatorname{I09}(\mathrm{I})$ ) But "the enforcement of the aforesaid principles may not alter the unitary character of the State" (Article Iog(3)). In fact, Article IIo(2) recognized that "places on the

\footnotetext{
2 See, for instance, N. Cojocaru, 'Nationalism and Identity in Transnistria', 19 Innovation: The European journal of Social Science Research (2006), 26I-272.
} 
left bank of the Dniester River may be assigned special forms and conditions of autonomy, according to the special statutory provisions adopted by organic law". This organic law that is regulating the special statute of the autonomous territorial units - only in the case of Gagauzia for the moment - may be amended with the vote of three fifths of the elected members of Parliament. Moldovan case in terms of path to solve secessionist movements has been really original in comparison with other examples in the community of independent states. ${ }^{3}$

We need to remember the procedure by which Moldovan Constitution was approved and after that was celebrated the independence referendum and the Gagauz Yeri-Gagauzia autonomy - was established. The republican referendum celebrated on March 6, 1994 had the goal to consult the population about the independence of the republic. That is to put an end to doubts about an eventual reunification with Romania. Despite not meeting the deadlines established by the Moldovan law of 1992 on the holding of referendums, that consultation was called and celebrated a week after the parliamentary elections. Final results approved by 97 , $9 \%$, the independence of Moldova as a state and ending the debates on reunification with Romania. In this situation, the main argument had disappeared for Transnistria and Gagauzia secessionist movements. The approval of the Constitution on August 271994 allowed a few months later the approval in the Moldovan Parliament of the Autonomous Territorial-Unit of Gagauzia on December 23, 1994. That was incorporated as new Article III in the Constitution. ${ }^{4}$

This special statute of autonomy can be considered an exercise of internal selfdetermination because any kind of external self-determination is contrary to the Constitution and territorial integrity of the republic. This special consideration with the Gagauze people could be understood as an interesting model for a definitive solution in Transnistria. At the same time, this type of solution allowed to Chisinau authorities to avoid the different projects of asymmetric federalism in which Transnistria and Gagauzia could have the ability to block central institutions. ${ }^{5}$ Nevertheless, there were a lot of projects and diplomatic solutions recovered during the following years trying to unlock the situation in Transnistria. For instance, the 1997 Moscow Memorandum -also named as the Primakov Memorandum-

\footnotetext{
3 Among others: Th. Burri, 'Secession in the CIS: Causes, Consequences, and Emerging Principles', in Ch. Walter, A. V. Ungern-Sternberg and K. Abushov (eds.), Self-determination and Secession in International Law (Oxford University Press, Oxford, 2014) I38-156.

4 Constitution of Moldova, entered into force August 27, 1994, available in the web of the Presidency, Constitution of the Republic of Moldova-Presidency of the Republic of Moldova, accessed June 20 2018.Art. IIO amended by the Law n ${ }^{\circ} 344-X V$ of 25 July 2003, MO nr 170-I72/08 August 2003, art. 72I

5 See on the different projects S. Roper 'Regionalism in Moldova: The Case of Transnistria and Gagauzia', II Regional and Federal Studies (200I), IOI-I22.
} 
and the 2003 Kozak Memorandum. ${ }^{6}$ Both of them were offered by the Kremlin and the main purpose was to offer unacceptable alternatives to Chisinau in order to maintain the current status quo. The flagrant violations of basic rules of international law were going to be maintained. At the same time Transnistrian secessionism was going to become a real Trojan horse within the Republic of Moldova. Due to the veto power granted to Transnistria, the federalist model became a permanent nightmare to guarantee governability and territorial integrity. Bosnia-Herzegovina and its complex constitutional and territorial system represent the best example in this sense. 7

The main constitutional provisions contained in Article III amended by the mentioned Law $\mathrm{n}^{\circ}$ 344-XV of July 252003 . Gagauzia is considered in III(I) "an autonomous territorialunit having a special statute and representing a form of self-determination of the Gagauzian people, shall constitute an integrant and inalienable part of the republic of Moldova and shall independently solve, within the limits of its competence, pursuant to the provisions of the Republic of Moldova Constitution, in the interest of the whole of society, the political, economic and cultural issues". The following points collected in the article establish the guarantee on all the rights and liberties foreseen by the Constitution: representative and executive bodies independent from Chisinau, own budget, natural resources control, and other specific rights according to the special statute of Gagauzia. Nevertheless, "the control over the observance of the Republic of Moldova legislation within the autonomous territorial-unit of Gagauzia shall be performed by the Government under the terms of the law" $(\operatorname{III}(6))$.

This type of autonomic model has become an interesting way of reconversion of a secessionist movement in an exercise of internal self-determination for ethnic minorities within the territory of a new independent state. Also respecting the rights of the rest of national minorities and the integrity territorial principle this solution has allowed to accommodate the basic rules of internal law within the internal legal order of the new Moldovan State.

The most important destabilizing factor has come as a result of events in Ukraine in the beginning of 20I4. The named Euromaidan, the Russian annexation of Crimea previous referendum of independence and the military conflict in Eastern districts of Ukraine-

\footnotetext{
6 See as a good example the web of Ministry of Foreign Affairs of Pridnestrovian Moldavian Republic in which is available full text of these Memorandums, accessed June 262018.

7 The full text of The Moscow Memorandum on the bases of the normalization of relations between the Republic of Moldova and Transdniestria, signed on May 8, 1997, accessed June 22 20I8. The full text of Kozak Memorandum signed on November 172003.

8 Emended articles of this law in The Constitution of the Republic of Moldova with changes made by the Law n $344-X V$ of 25 July 2003 , accessed June 282018.
} 
Donetsk and Lugansk mainly have been important in terms of agitation for all the secessionist movements of the former space. In this complex situation Moldova and also Ukraine and Georgia signed their Association Agreement with the European Union. The immediate reaction of Gagauzia's leaders was the celebration of a referendum in the autonomous territory in February 20I4. The population was called for a triple consultation: 98.4\% was favourable to establish closer ties with the Euroasiatic Economic Union-this is the economic integration project managed by Russia - 97.2\% rejected a future integration within the European Union; by last, $98.9 \%$ of total voters supported Gagauzia's right to declare its independence if Moldova ceased to be independent. This possibility was not new. In fact several proposals made by the CSCE - not OSCE until 1995 - from the first reports issued by the Mission established in Chisinau in 1993 collected this possibility including also Transnistria's secessionist movement. ${ }^{9}$ If Moldova tried to join Romania, the CSCE Mission proposed that Transnistria could exercise the right of external self-determination. Nevertheless, it was a strong recommendation to Moldova in order to proceed to a broad territorial decentralization. This possibility could make the territorial integrity of Moldova compatible with a broad autonomy for Transnistria and Gagauzia. These special regions, according to the denomination collected in the Constitution of Moldova, could enjoy their own local institutions - executive, legislative, judicial — as integral parts of the republic with some shared competences. As we can see, Gagauze people chose this option. The absence of the Russian support was definitive to finish the Independence path and instead of that continue with the autonomist path.

The experience during two decades and a half in the development of the Gagauze people, with a direct election of their own government, has been successful. Ethnic and cultural identity has been protected in the general framework of the Republic of Moldova. In fact, this model is considered one of the most advanced examples in Eastern Europe and in the postSoviet space..$^{\text {Io }}$

\section{(C) SECESSIONISM IN TRANSNISTRIA}

This territory has been a complex scenario due to a turbulent historical evolution. During the period of Perestroika Transnistria was probably the first example of ideological political confrontation at the beginning of 1989. The supporters of the Soviet Union and the

\footnotetext{
9 See this complete work on CSCE/OSCE contribution to establish different political and diplomatic solutions to the whole of post-Soviet conflicts, M. Raquel, Conflict and Security in the Former Soviet Union: The Role of the OSCE, specially 'Case-study: The OSCE in Moldova' (Routledge, New York, 2018)

ro Confirmed by the reports of the OSCE Mission in Moldova, accessed June 292018.
} 
communist structures were losing ground in front of the increasingly numerous supports of the republican independence and the construction of the new independent state. The main argument held by the separatists was the same than in Gagauzia: exploiting the fear of an eventual reunification between Moldova and Romania in case of rupture with the Soviet Union. Russian and Ukrainian minorities living in the region shared this feeling at the beginning of 1989 and especially when the Language Law was approved. But, the unilateral independence declaration made by Transnistria on September 31990 was previous to the independence of Moldova on August 27 199r. Thus, the Pridnestrovian Moldavian Soviet Socialist Republic was proclaimed as a Soviet republic. The reaction from Moscow was ambiguous and lacking in support for the territorial integrity of the republic. The secessionist leaders were violating international and soviet internal legality. The second one allowed the right of secession only in the case of the federated republics of the Soviet Union. This constitutional provision was not recognised for other territorial entities as the autonomous republics within federal republics. It is necessary to remember that neither Transnistria nor Gagauzia enjoyed a differentiated status within the Soviet Socialist Moldavia Republic.

When the Belavezha Treaty on December 8 1991 confirmed the dissolution of the Soviet Union and Moldova was recognized as an independent state, the reunification with Romania was not present in the different political projects. Moldova Popular Front was losing their strong presence in the Parliament and the construction of the new statehood was the main priority. The recognition of the rights of ethnic minorities and their protection in accordance with international standards became the main objective. Also the possibility of exercising the internal self-determination through special autonomy status collected in the Constitution of 1994 was definitive for the absence of all kinds of arguments in the position of Transnistria. There was no legitimacy or legality —neither internal nor international— to endorse Transnistrian separatism.

The war between March and July in 1992 ended with the confirmation of Transnistria as an independent territorial entity. This de facto independence was impossible without the Russian support during and after the war. Territorial integrity was questioned shortly after international recognition of Moldova. On July 2I 1992 a peace agreement was reached in between Moldova and Russia. Since the short war between Moldova and the secessionists in Transnistria it lasted four months there had not been new military clashes after the cease fire agreement of July 1992. The parties were committed to establish political negotiations between the Moldovan and Transnistrian authorities. The main goal was to reach a definitive territorial status for Transnistria within Moldova. This question remains pending since that moment transforming this separatist entity into a frozen conflict. During those twenty-five years there were many diplomatic solution projects presented by the main international 
actors. In addition, different political and legal projects have been analysed in the OSCE framework and other bilateral meetings. ${ }^{\text {II }}$

Meanwhile, the different negotiation and diplomatic mediation processes have been led by Moscow being judge and party with strong interests. In this context, all the attempts have failed..$^{12}$ This situation has lasted until today and de facto independence is the best scenario for the strategic interests of the state patron Russia and for this puppet state. The XIV Soviet Army installed in Transnistria from the Soviet period became an interposition force after the war and obviously the main Russian tool in the area. ${ }^{13}$

It is remarkable the celebration of a double referendum of independence celebrated on September 172006 violating the internal and international legality. The results were the following: $3.39 \%$ renounced the independence of the territorial enclave and supported an eventual reintegration in Moldova; on the other hand, 96.6r\% of total voters opposed both possibilities. Also 98.07\% supported the independence and a future integration in Russia. The total participation was $77.55 \%$. These results were not considered by Chisinau due to the illegality of the referendum. However, the separatist authorities claimed for that after the referendum celebrated in Crimea on March 16 2014. At that moment, they asked the United Nations to recognize their independence. This request was also transferred to OSCE and Russia appealing to the right of self-determination of people.

\section{(D) TRANSNISTRIA VS GAGAUZIA}

The presence and importance of Russian patronage has been the determining factor in the evolution, freezing or eventual resolution of secessionism in Moldova, as it happened in the whole of secessionist movements in the former Soviet space. Both shared their origins as a reaction to the independence of the republic and its eventual reunification with Romania. However, despite relying on purely political-ideological criteria both broke international and soviet legality. The main political argument was the maintenance within the Soviet Union. But during this period, from 1989 to August 27 1991-declaration of independence in Moldova - it did not respond to the real situation. In that convulsive reformist period, neither Transnistria nor Gagauzia could exercise any form of internal or external selfdetermination in the legal soviet framework, since the right of secession was only reserved to the fifteen federated republics. The subsequent evolution in the construction of independent

\footnotetext{
II See, for example, S. Wolff, 'A resolvable frozen conflict? Designing a settlement for Transnistria', 39(6) Nationalities Papers (2011) 863-870.

I2 A brief synthesis of proposed solutions and bilateral developments: N. Belitser, 'The Transnistrian conflict', A. Bebler (ed.) "Frozen conflicts" in Europe, (Barbara Budrich Publishers, Berlin, 2015) 44-55.

I3 W. Alejandro Sánchez, 'The "Frozen” Southeast: How the Moldova-Transnistria Question has Become a European Geo-Security issue', 22(2) The Journal of Slavic Military Studies (2009) I53-176.
} 
statehood - with the Constitution of 1994- allowed the creation of different special status for Gagauzia and Transnistria as explained above. These constitutional provisions could be considered as a way of internal self-determination, especially for two territorial entities without any prior special status. This possibility has only been used by Gagauzia and sometimes by Transnistria due to the Russian political, economic and military support.

There are some theories on state building process starting from de facto structures due to the time factor. In this case, Transnistria would have many options to transform temporary institutions into permanent as long as Russia maintains its economic, political and military support. ${ }^{14}$

The effectiveness principle has been specified both in Transnistria and Gagauzia. They maintain territorial control by breaking the territorial integrity of Moldova.In addition, it shows even clearly in the case of Transnistria, due to the support of the Russian Army. The effective and stable government has been a more relevant element in Transnistria with a rapid construction of independent institutional structures. The attribution of legal consequences has been once more supported by Moscow. Russia paid attention since 1992 to all the separatist political movements building a set of puppet governments on the periphery of the former Soviet Union. Nevertheless, effectiveness is strongly dependent on the Russian patronage support. This country controls the processes of political leadership exploiting economic dependence and energy captivity. In addition, the permanent presence of the Russian Army in terms of security is essential. Last and not least, this is connected with an extreme institutional fragility, much closer to post-totalitarianism than pre-democracy.

International recognition is absent in both cases: Gagauzia never requested it; Transnistria has been recognized by the rest of secessionist entities in the post-Soviet region (NagornoKarabaj, South Ossetia and Abkhazia) and Russia opened a consular office in Tiraspol. Unlike Gagauzia, where the autonomist way seems to triumph since 1994, the secessionism seems to have won the battle to the parent state (Moldova). The illegality of the declaration of independence has not prevented the consolidation of a de facto State. Time is really important although is not an irreversible process. In fact, Chisinau authorities have persisted in a not acquiescent attitude byclaiming the territorial integrity.

Respect for international legality as a necessary condition for the acquisition of an independent state has not been a characteristic feature in both processes. Therefore, as it happened with the rest of the frozen conflicts, the international community has sanctioned these secessionist movements with the practice of international non-recognition. The

I4 This theory is developed in H. Blakkisrud and P. Kolsto, 'From Secessionist Conflict toward a Functioning State: Processes of State-and Nation- Building in Transnistria', 27(2)Post-Soviet Affairs (20II), I782 IO. 
violation of the structural principles contained in the United Nations Charter - especially the use of armed force and territorial integrity of the states-makes illegal the access of these territorial entities to independence, even in those cases of succession of states. If we understand as secession the effective separation of a territory from the parent State without its acquiescence, we would need the concurrence of other situations that confer legality to the new status-submission by force, racist government or colonial power by foreign powers. It has not been the case neither in Transnistria nor in Gagauzia. On the other hand, the illegality of unilateral declarations of independence - at least until the controversial ruling of the International Court of Justice- has been persistent in the case of Transnistria. ${ }^{.5}$

International regulations on human rights and especially in the protection of the rights of peoples and ethnic minorities - since United Nations General Assembly Resolution 2625 (XXV) of October 24, 1970 and the complete legal instruments of Council of Europe and OSCE - have been taken over by the Republic of Moldova. This evolution invalidates by unnecessary and unjustified the legal assumption considering secession as a remedy. In both cases (Transnistria and Gagauzia) there was not any massive violation of human rights or humanitarian reasons. Moreover, in Transnistria the violations - especially in terms of linguistic rights - have been suffered by the Moldovan-Romanian population.

Moldovan language is not considered as official language in this territory not even as a language in teaching due to the presence of Russian language..$^{16}$

Considered as an imperfect secession because of a strong dependence of Russia, both movements took advantage of political circumstances of the dissolution of a federal state and multi-ethnic character. This messy process of succession of States was used by several political elites in different republics in order to build an independent statehood. The Russophile base in Transnistria was very identified with the Soviet system. Unlike what happened in Abkhazia or South Ossetia - even in Kosovo-, both cases analysed did not suffer any loss of previous territorial status-autonomy, autonomous region or autonomous republic. In fact, the application of the constitutional provision for Transnistria is still pending. However, as we have verified through the investigation it has been impossible to solve it due to the Russian intervention in the process both from the diplomatic sphere and in the internal interference in Moldova. Path to autonomy is not on the agenda of Moscow. As long as Transnistria will be a useful tool for the geostrategic interests of Russia in its near

is See on Kosovo ICJ the monographic volume dedicated to the advisory opinion, 63(I) Revista Española de Derecho Internacional (20II)

I6 See J.A. López, 'Transnistria: evolución de un modelo de secesionismo en el seno de la República de Moldova (1995-2000)', in M.D. Algora y C. Flores (ed.) Estudios sobre la Europa Oriental (Universitat de València, Valencia, 2002) 307-329. 
abroad, this territorial entity will be used in terms of foreign affairs policy. Otherwise,Transnistria will never be really an independent statehood, not only from Moldova but from Russia as well. ${ }^{17}$

Finally, with regards to the so named political doctrines of the recognition of states-not contemplated by Contemporary International Law — we can note that it is impossible to consider this possibility in both secessionist processes within Moldova. Neither Gagauzia, until the creation of the special autonomy, nor Transnistria had any historical situation that needed to be repaired, as for instance in the case of Crimea. Neither did the majority proindependence will of a people exist, since the majority national minorities (Moldovan, Ukrainian and Russian) had already their own parent state. Rather it was about keeping a political and economic model by regional elites in the context of the dissolution of a system and a State. Therefore, the identification of nations, peoples and independent States has very specific profiles in the Transnistria's model.

From the International Law perspective, the different unilateral declaration of independence in the separatist territories involves the obligation of non-recognition. This is the answer of the international community - States and international organizations, mainly United Nations - as a sanction against the violation of structural principles and ius cogens imperative rules: general prohibition of the use of threat and/or force, territorial integrity and sovereignty, and no internal interference in the States. All of which has been forced by Russia in these conflicts.

As a conclusion, we can point out two different considerations: the secessionism in Gagauzia has been redirected endowing it with a special status within the Moldovan territory and giving an internal dimension to the exercise of self-determination. This option has not been explored in Transnistria due to different reasons: absence of political will of the secessionist leaders supported by the Russian external patronage. Moscow has a very marked and differentiated interest in foreign affairs on the two territories. Therefore, while Russia needs the presence of a puppet state sine die - the model of Transnistria- in the case of Gagauzia does not have any particular interest. In addition, Tiraspol sees Gagauzia as "an antimodel" ${ }^{18}$ Therefore, the final solution in this entity was possible within Moldova and according to the international and internal law. This also explains how the various

${ }_{17}$ This is the thesis followed by A. Devyatkov, 'Russian Policy toward Transnistria. Between Multilateralism and Marginalization', 59(3) Problems of Post-Communism(2012) 53-62.

r8 S. Wöber, 'Making or Breaking the Republic of Moldova? The Autonomy of Gagauzia', EDAP (European Diversity Autonomy Papers) (Eurac Research, Bolzano, 2013) I-52. 
negotiating formats tried on Transnistria, mainly through the OSCE, have failed and in all likelihood, the conflict will be kept in the freezing phase.19

19 E. Fouere, 'OSCE's efforts to resolve the conflict', in A. Bebler (ed.), "Frozen Conflicts" in Europe (Barbara Budrich Publishers, Berlín, 2015) 57-68. 